But acarlemic science also stimulates industrial innovation and prosperity. and MTT has Route 128 around Boston to prove it. But "if this formula was so successful, why are we abandoning it ?... Science and technology are in retreat, not only in the universities but in industry and in the country as a whole".

The effects on the cuts on the balance between graduate and undergraduate education were the chief concern of Dr Charles L. Hosler. who also provided the most elaborate oratory last week. He said that the proportion of undergraduates staying on for graduate schools was already declining, even though it was more than ever clear that "much of our BS training has become superficial. . . and there is not enough time in the four-year program to give a student the breadth and depth that many of today's programs require". In Dr Hosler's experience BS graduates in the United States are now being diverted from the graduate schools by the attractive starting salaries which they are offered in industry. Like other speakers, he was anxious that there should bo enough highly trained people "to solve tomorrow's unknown problems". For the benefit of those who are more directly concerned with simple profit and loss, he produced a calculation that the extra $\$ 100,000$ which a $\mathrm{PhD}$ graduate could expect to earn in the course of his working life would vield an extra $\$ 20,000$ in taxes, more than enough to pay for the cost of a graduate sehool stipend.

President Nixon's campaign statement that "scicntific research cannot be turned off and on like a faucet" was thrown back last week by Dr Thomas Jones, president of the University of South Carolina, who feared that the effects of the Mansfield amendment would be especially severe for universities not in the first flight of acadenic rescarch institutions. Surely the Federal Government, which some years ago was urging universities like his own to develop new graduate schools, now had a duty to continue to provide for them. In the event, at times like the present when institutions are competing for diminishing funds, "the ripples spread outwards as the prestigious institutions" shoulder aside their weaker fellows. One result had been that in the University of South Carolina, the amount of new rescarch grant support for 1970 will be only a half that obtained in $\mathbf{1 9 6 9}$.

Dr Davics also regretted the way in which the first report of the National Science Board, which in 1969 urged that graduate education should be accepted as a federal responsibility, "has received so little attention". He thought it essential that graduatc education should be widely spread across the United States, with at least one strong centre of scientific rescarch in every state. The alternative methods for financing graduate schools spelled out by the National Science Board deserved consideration.

The word "catastrophe" was used on several occasions during the session last week to describe the consequences of the impending shortage of money for basic rescarch. Several witnesses urged that the rate at which grants are reduced should at least be matched to the time-scale of forward planning in the universities. The chairman of the subcommittee, Mr Daddario, said that arranging that universities could safely plan ahead is largely "an institutional problem". The season of talk about the creation of new agencies is evidently about to be reopened.

\section{Consequences of Mansfield}

THe report of the Research Management Advisory Pancl (Mission Agency Support of Basic Research) is a brief but forceful document. "The colleges and universities of the United States are an cssential national resource, central to stability, economic progress and security" and "the present science establishment of the United States is unique". But "most universities in the United States are experiencing severe financial strains which threaten their very existence as economically sound national resources in the sciences". Only the Federal Government can sustain academic science. "National policy has recognized the justification for Federal Government support of seicnce for the past 25 years. At the heart of this crisis in our universities is academic science, both research and training. These are in jeopardy."

The report goes on to list the pressures on academic research-larger enrolments, increasingly expensive equipment and facilities, inflation, the development of interdisciplinary programmes and the involvement of scholars in. scveral kinds of public service. Yet federal spending on academic science has not kept pace with inflation and "we enter the 1970 s with a greater need for scientific knowledge but faltering support for scientific rescarch".

The pancl is alarmed because this trend threatens to undermine "our recently won leadership in science". ... Government support for university research has become unstable and unpredictable. It is actually decrcasing in several fields of science and is now inadequate in virtually all scientific disciplines. The Federal Government . . . is now treating university basic science as a luxury it can no longer afford... the always precarious balance of university financial needs and funding support for science is being destroyed. The universities must be, and are, willing to accept budget constraints, but "recent abrupt actions of the Federal Government have set arbitrary ceilings, cut appropriations for the National Science Foundation and redesignated the criteria under which Department of Defense appropriations may be spent. The results of these actions have been most serious. University administrators are unable to maintain coherent programs in the face of sudden changes in Government practice, for which there has been little warning".

The report goes on to say that the Mansfield amendment is "potentially disruptive" and urges that the "Federal Government carefully consider the disruption that an overly restrictive interpretation... . would have on the close contacts of those who work in applied science and engineering". The pancl also draws attention to the way in which the new developments put in hazard the "historic national policy that each mission department and agency which draws upon science in its operation should support its proper share of the country's research". 